\title{
Endogenous Galanin Protects Mouse Hippocampal Neurons Against Amyloid Toxicity in vitro via Activation of Galanin Receptor-2
}

\author{
Caroline R. Elliott-Hunt ${ }^{\mathrm{a}}$, Fiona E. Holmes ${ }^{\mathrm{a}}$, Dean M. Hartley ${ }^{\mathrm{b}}$, Sylvia Perez ${ }^{\mathrm{b}}$, Elliott J. Mufson ${ }^{\mathrm{b}, *}$ \\ and David Wynick ${ }^{\mathrm{a}, *}$ \\ ${ }^{a}$ Schools of Physiology and Pharmacology and Clinical Sciences, University of Bristol, Bristol, UK \\ ${ }^{\mathrm{b}}$ Department of Neurological Sciences, Rush University Medical Center, Chicago University, Chicago, IL, USA
}

Accepted 18 February 2011

\begin{abstract}
Expression of the neuropeptide galanin is known to be upregulated in the brain of patients with Alzheimer's disease (AD). We and others have shown that galanin plays a neuroprotective role in a number of excitotoxic injury paradigms, mediated by activation of the second galanin receptor subtype $\left(\mathrm{GAL}_{2}\right)$. In the present study, we investigated whether galanin/GAL2 plays a similar protective role against amyloid- $\beta(A \beta)$ toxicity. Here we report that galanin or the $\mathrm{GAL}_{2 / 3}$-specific peptide agonist Gal2-11, both equally protect primary dispersed mouse wildtype (WT) neonatal hippocampal neurons from $250 \mathrm{nM} A \beta_{1-42}$ toxicity in a dose dependent manner. The amount of $A \beta_{1-42}$ induced cell death was significantly greater in mice with lossof-function mutations in galanin (Gal-KO) or $\mathrm{GAL}_{2}\left(\mathrm{GAL}_{2}-\mathrm{MUT}\right)$ compared to strain-matched WT controls. Conversely, cell death was significantly reduced in galanin over-expressing (Gal-OE) transgenic mice compared to strain-matched WT controls. Exogenous galanin or Gal2-11 rescued the deficits in the Gal-KO but not the GAL2-MUT cultures, confirming that the protective effects of endogenous or exogenous galanin are mediated by activation of $\mathrm{GAL}_{2}$. Despite the high levels of endogenous galanin in the Gal-OE cultures, the addition of exogenous $100 \mathrm{nM}$ or $50 \mathrm{nM}$ galanin or $100 \mathrm{nM} \mathrm{Gal2}-11$ further significantly reduced cell death, implying that $\mathrm{GAL}_{2}$-mediated neuroprotection is not at maximum in the Gal-OE mice. These data further support the hypothesis that galanin over-expression in $\mathrm{AD}$ is a neuroprotective response and imply that the development of a drug-like $\mathrm{GAL}_{2}$ agonist might reduce the progression of symptoms in patients with $\mathrm{AD}$.
\end{abstract}

Keywords: Alzheimer's disease, amyloid toxicity, galanin, $\mathrm{GAL}_{2}$, neuroprotection, transgenic models

Supplementary data available online: http://dx.doi.org/10.3233/JAD-2011-110011

\section{INTRODUCTION}

The pathological hallmarks of $\mathrm{AD}$ are the presence of neurofibrillary tangles and senile plaques.

\footnotetext{
${ }^{*}$ Correspondence to: David Wynick, Medical Sciences Building, University Walk, Bristol BS8 1 TD, UK. Fax: 441173312288 ; E-mail: d.wynick@bris.ac.uk and Elliott Mufson, Department of Neurological Sciences, Rush University Medical Center, 1735 West Harrison Street, Suite 300, Chicago, IL 60612, USA. Fax: 00101312 563 3571; E-mail: emufson@ rush.edu.
}

The amyloid- $\beta$ (A $\beta$ ) peptide, a predominantly $40-42$ amino-acid fragment of the amyloid- $\beta$ protein precursor $(\mathrm{A} \beta \mathrm{PP})$ derived from the cleavage of A $\beta P P$ by $\beta$ and $\gamma$-secretases [1], is the major component of neuritic plaques [2]. $A \beta$ deposition triggers a long-term neuropathological cascade, which includes neuronal loss and markedly distorted axons and dendrites, which lead to dendritic regression and spine loss [3, 4]. Dystrophic neurites are typically associated with senile plaques and both are correlated with cognitive deficits 
[5]. Neurites contain a large number of neurotransmitter and neuromodulatory substances, which are for the most part, reduced in the AD brain [6]. By contrast, the expression of the neuropeptide galanin $[7,8]$ is increased in $\mathrm{AD}[9,10]$. In $\mathrm{AD}$, thickened galanin-immunoreactive fibres hyper-innervate surviving cholinergic basal forebrain ( $\mathrm{CBF}$ ) neurons, the locus coeruleus, as well as cortical and hippocampal projection neurons [9-12]. Further, galanin peptide levels as well as galanin receptor binding sites are increased in the neocortex, hippocampus, amygdala, and basal forebrain in the AD brain [13-17]. Studies using mice transgenic for A $\beta P P$ bearing familial AD-related gene mutations exhibit age-dependent increases in hippocampal galanin neurite formation in close opposition to amyloid containing plaques $[18$, 19]. These hypertrophied galaninergic fibers are thickened with bulbous endings [18], very similar to that observed in AD.

The above findings have led to a number of functional studies addressing the role played by galanin in the modulation of acetylcholine (ACh) release, learning, and memory. The injection of galanin into the rat ventral hippocampus inhibits scopolamine-stimulated ACh release and impairs spatial learning acquisition in the water maze [20, 21]. Conversely, application of the peptide into the dorsal hippocampus stimulates the release of ACh and facilitates spatial learning [22, 23]. These site-specific effects are mirrored by the findings that galanin binding sites are present in both the ventral and dorsal hippocampus, but with fivefold higher concentrations in the ventral hippocampus [24]. Transgenic mice with ectopic over-expression of galanin localized to the adrenergic neurons (using the $\mathrm{DBH}$ promoter) have deficits in spatial learning and acquisition in the water maze [25], while mice with more widespread ectopic galanin over-expression (using the PDGF promoter) have normal learning and memory retention in the water maze task, compared to wild-type (WT) controls [26]. These studies have led some investigators to postulate that the up-regulation of galanin in AD might be detrimental and would further impair cognition [20, 25]. In contrast, it has also been hypothesized that amyloid-induced galanin fiber over-expression in AD plays a trophic and neuroprotective role to minimize the impact of amyloid toxicity upon neuronal function and cell survival.

To further study the role of galanin in neuronal survival and growth, we have generated transgenic mice bearing loss- or gain-of-function mutations in the galanin gene [27, 28], and demonstrated that the neuropeptide acts as a survival factor to subsets of neurons in the dorsal root ganglia (DRG) and CBF [29, 30]. Further, the peptide is a trophic factor to adult sensory neurons, which are dependent upon galanin for neurite extension after injury [31], mediated by activation of the second galanin receptor subtype $\left(\mathrm{GAL}_{2}\right)$ [32]. We have also demonstrated that galanin and Gal2-11 (which has 500-fold selectivity for $\mathrm{GAL}_{2}$ and $\mathrm{GAL}_{3}$ compared to $\mathrm{GAL}_{1}[33,34]$ ) both play a neuroprotective role in the central nervous system (CNS) by reducing cell death in in vivo and in vitro hippocampal models of excitotoxicity [35]. We have extended these findings using the above injury paradigms of neuronal injury by applying them to the Gal-KO, GAL 2 -MUT, and Gal-OE mice. Collectively, these data demonstrate that the neuroprotective role played by galanin in the hippocampus is mediated by activation of $\mathrm{GAL}_{2}$, and is abolished in GAL 2 -MUT mice [36]. Of note, there is no evidence to date that the developmental cell survival role played by galanin in the basal forebrain alters or modulates the neuroprotective role played by galanin/GalR2 in the adult after neuronal injury.

Most recently, several studies have demonstrated that the addition of exogenous galanin or Gal2-11 is neuroprotective against $A \beta$ toxicity in primary rat hippocampal [37] or cholinergic [38] cultures, human fetal brain cultures [39], and in the SN56 cholinergic cell line [40], and maintains or increases the expression of cell survival genes in the AD basal forebrain [41]. Here we show by modulation of endogenous levels of galanin or $\mathrm{GAL}_{2}$ in transgenic mice, that the neuropeptide has a significant neuroprotective role against $A \beta$ toxicity via activation of $\mathrm{GAL}_{2}$. These data further support the hypothesis that galanin over-expression in $\mathrm{AD}$ is a neuroprotective response and imply that the development of a drug-like $\mathrm{GAL}_{2}$ agonist might reduce the progression of symptoms in patients with this disease.

\section{MATERIALS AND METHODS}

\section{Animals}

All animals were fed standard chow and water ad libitum and animal care and procedures were performed within the United Kingdom Home Office protocols and guidelines.

\section{Galanin over-expressing (Gal-OE) mice}

Details of the strain and breeding history are as described [27, 42]. In brief, galanin over expressing mice, bred to homozygosity, were generated using a $\sim 25 \mathrm{~kb}$ transgene containing the entire murine galanin coding region and $19.9 \mathrm{~kb}$ of upstream sequence. 
The transgene was excised by restriction digest and microinjected into fertilized oocytes. The transgenic line denoted OE2 was then bred and characterized (see Bacon et al. for further details [42]). The line has remained inbred on the CBA x C57BL6 (CBA/B16) F1 hybrid background. WT mice that were strain-, age-, and gender-matched were used as controls in all experiments.

\section{Galanin knockout (Gal-KO) mice}

Details of the strain and breeding history are as described [28]. In brief, mice homozygous for a targeted mutation in the galanin gene were generated using the E14 cell line. A PGK-Neo cassette in reverse orientation was used to replace exons $1-5$, and the mutation was bred to homozygosity and has remained inbred on the 1290laHsd strain. Strain-, age-, and gender-matched WT mice were used as controls in all experiments.

\section{$G A L_{2}$ mutant $\left(G A L_{2}-M U T\right)$ mice}

Details of the strain and breeding history are as described [32]. In brief, mice deficient for the GALR2 gene were generated and licensed from Lexicon Genetics. The $5.17 \mathrm{~kb}$ gene-trap vector VICTR48 (VIral Construct for TRapping) was inserted within the single intron of the murine GAL2 gene in a $129 \mathrm{~Sv} / \mathrm{EvBrd} \mathrm{ES}$ cell line clone [43]. Omnibank clone OST105469 was used to obtain germ-line transmission of the disrupted GALR2 allele. Heterozygote pairs on the C57BL6 x 129SvEvBrd (B16/129 Sv) background were transferred to the University of Bristol and then bred to homozygosity and have been maintained on that background. Strain-, age-, and gender-matched WT mice were used as controls in all experiments.

\section{Preparation of primary neuronal cultures}

Hippocampi from 2- to 3-day-old mouse pups were dissected and placed into $4^{\circ} \mathrm{C}$ collection buffer prepared with Hanks' balanced salt solution (calcium and magnesium free) (GIBCO/BRL), $10 \%$ 4-(2-hydroxyethyl)-1-piperazineethanesulfonic acid (HEPES, ICN), $10 \mu \mathrm{g} / \mathrm{ml}$ Penstrep (GIBCO/BRL), and $0.5 \%$ Bovine Serum Albumin (ICN). Enzymatic digestion, isolation, and culture of hippocampal neurons were performed as previously described [35], with the exception of the substitution of $0.83 \mathrm{U} / \mathrm{ml}$ Dispase (Sigma) instead of Trypsin. To inhibit glial cell growth, 5'Fluoro 2' Deoxyuridine (Sigma), was added $(10 \mu \mathrm{g} / \mathrm{ml})$ to the cultures after $24 \mathrm{~h}$. Cells were counted and plated at 40,000 cells/well onto
DL-polyornithine-coated (Costar) black-wall 96-well plates (Corning, Arlington, UK). Cells were placed in Minimal Essential Media (GIBCO/BRL), with 5\% Fetal Bovine Serum (GIBCO/BRL), 5\% Horse Serum (GIBCO/BRL), $2 \mathrm{mM}$ L-Glutamine (GIBCO/BRL), $5 \mu \mathrm{g} / \mathrm{ml}$ Insulin (Sigma), $10 \mathrm{ug} / \mathrm{ml}$ Penstrep and $5 \mathrm{mM}$ HEPES for $2 \mathrm{~h}$ before media was changed to Neurobasal media, as described [35]. Cultures were incubated at $37^{\circ} \mathrm{C}$ with ambient oxygen and $5 \% \mathrm{CO}_{2}$ for 5 days before experimentation and the media was changed on the fourth days.

\section{Preparation of fibrillar $A \beta\left(f A \beta_{1-42}\right)$}

A $\beta_{1-42}$ (American Peptide Company Inc., USA) was dissolved in dimethyl sulfoxide (DMSO, Sigma) and then diluted to a concentration of $1 \mathrm{mM}$ in phosphate buffered saline (PBS, Sigma) and incubated at $22^{\circ} \mathrm{C}$ or $37^{\circ} \mathrm{C}$ for 24 or $48 \mathrm{~h}$. Electron microscopy was then undertaken at the University of Bristol central imaging facility. A $5 \mu \mathrm{l}$ drop of the $\mathrm{A} \beta_{1-42}$ suspension was placed on a formvar and carbon coated copper grid and left to dry for $5 \mathrm{~min}$. Excess fluid was removed using a filter paper and the grid was placed on top of a 3\% Uranyl acetate solution in water. After $1 \mathrm{~min}$ excess fluid was removed using filter paper and air dried. The sample was examined using a FEI Tecnai12 Biotwin equipped with a $4 * 4 \mathrm{k}$ bottom-mounted EAGLE CCD camera. Results demonstrated that incubating the peptide at $37^{\circ} \mathrm{C}$ for $48 \mathrm{~h}$ resulted in material that displayed a predominantly fibrillar form (Supplementary Fig. 1; available online: http://www.j-alz.com/issues/25/vol253.html\#supplementarydata01). That protocol was then used to generate $f A \beta_{1-42}$ for all future experiments.

\section{Treatments}

Dispersed primary hippocampal cultures were cultured with or without the addition of the following: fA $\beta_{1-42}$, L-glutamic acid (Sigma), galanin peptide (Bachem), or Gal2-11 (Astra-Zeneca, Montreal).

\section{A $\beta_{1-42}$ Hippocampal toxicity}

Dispersed primary hippocampal cultures were exposed to concentrations varying from $1 \mu \mathrm{M}$ to 500 $\mu \mathrm{M} \mathrm{fA} \beta_{1-42}$ for $48 \mathrm{~h}$ or glutamic acid for $3 \mathrm{~h}$ with or without the addition of varying concentrations of galanin or Gal2-11. Neuronal injury was measured by the presence of propidium iodide. After membrane injury, the dye enters cells, binds to nucleic acids, and accumulates, rendering the cell brightly flu- 
orescent. The viability of neurons was measured by counting of both live and dead neurons using high content microscopy and analysis using the IN Cell Analyser 1000 microscope as previously described $[44,45]$. Image acquisition and quantification of fluorescence intensity and localization was performed using IN Cell Analyzer Workstation 3.5 software (IN Cell Investigator, GE Healthcare, Amersham, UK). Red channel (propidium iodide) and blue channel using 4',6-diamidino-2-phenylindole (DAPI) images were used to define whole-cell and nuclear regions, respectively. Images were acquired with two single fields of view $\left(0.6 \mathrm{~mm}^{2}\right)$ and a $10 \times$ objective. A total of $300-500$ cells per field were typically analyzed, and up to two fields per well were captured in experiments performed in triplicate, meaning that in each experiment, data were normally derived from at least 1000 individual cells per treatment.

\section{Statistical analysis}

Data are presented as the mean \pm SEM. Student $T$-test or one-way ANOVA with appropriate posthoc comparison tests were used to analyze difference between genotypes and the different ligands. Level of significance was set at $p<0.05$.

\section{RESULTS}

Exogenous galanin and Gal2-11 protect WT hippocampal cultures from $f A \beta_{1-42}$-induced cell death

We first studied fA $\beta_{1-42}$-induced cell death in dispersed neonatal hippocampal cultures from the three WT strains. In all strains $48 \mathrm{~h}$ exposure to fA $\beta_{1-42}$-induced a concentration-dependent increase in cell death with little or no consistent cell death at less than $25 \mathrm{nM}$, whereas at concentrations above $500 \mathrm{nM}$ virtually all cells died and detached from the culture plate and therefore, could not be accurately counted (data not shown). $250 \mathrm{nM}$ fA $\beta_{1-42}$ reproducibly induced cell death in all three WT strains (varying between $31.6 \%$ and $36.5 \%$, Figs. 1 and 2 and Supplementary Fig. 2; available online: http://www.j-alz.com/issues/25/vol253.html\#supplementarydata01) and this concentration was used for all future experiments. As a positive control 5-6 mM glutamate was used to induce a similar amount of apoptosis (varying between $28.9 \%$ and $34.9 \%$ ) to that observed with $250 \mathrm{nM}$ fA $\beta_{1-42}$ (Figs. 1 and 2).
Galanin and the $\mathrm{GAL}_{2 / 3}$ peptide agonist Gal2-11 both demonstrated similar degrees of significant dosedependent neuroprotection in dispersed hippocampal neurons from all three wildtype strains when exposed to $250 \mathrm{nM}$ fA $\beta_{1-42}$ (Figs. 1 and 2 and Supplementary Fig. 2). Maximum neuroprotection was obtained with $100 \mathrm{nM}$ galanin varying between $52 \%$ and $81 \%$ and $51 \%$ and $84 \%$ for $100 \mathrm{nM} \mathrm{Gal2-11.} \mathrm{Similarly,} 100 \mathrm{nM}$ galanin was neuroprotective after exposure to glutamate, and significantly reduced cell death between $51 \%$ and $76 \%$, similar to our previously findings [35, 36]. Treatment with galanin or Gal2-11 alone had no effect on cell death in any of the WT strains (Figs. 1 and 2). Of note, galanin and Gal2-11 both demonstrated greater neuroprotection in the B16/129 Sv mice, especially at lower concentrations, than in the two other strains studied (Figs. 1 and 2).

Transgenic manipulation of endogenous galanin and $G A L_{2}$ levels modulate $f A \beta_{1-42}$-induced hippocampal cell death and responses to exogenous galanin and Gal2-11

Cell death in Gal-KO and $\mathrm{GAL}_{2}$-MUT mice after exposure to $\mathrm{fA} \beta_{1-42}$ was significantly increased by $22 \%$ and $23 \%$ respectively, and by $23 \%$ and $38 \%$ respectively with glutamate, when compared to strainmatched WT controls (Fig. 1). Conversely, cell death was significantly reduced in Gal-OE mice by $51 \%$ and $38 \%$ after exposure to $\mathrm{fA} \beta_{1-42}$ or glutamate, respectively when compared to strain-matched WT controls (Fig. 2).

Exogenous galanin and Gal2-11 both fully and equally rescued the above deficits in the Gal-KO mice after exposure to $\mathrm{fA} \beta_{1-42}$ or glutamate (Fig. 1A). In contrast, neither peptide had any effect in the $\mathrm{GAL}_{2}$ MUT cultures (Fig. 1B). Despite the high levels of endogenous galanin in the Gal-OE cultures and the significant reduction in cell death, the addition of either exogenous $100 \mathrm{nM}$ or $50 \mathrm{nM}$ galanin or $100 \mathrm{nM}$ Gal211 further significantly reduced cell death in these mice (Fig. 2).

\section{DISCUSSION}

We and others have shown that transgenic manipulation of the endogenous levels of galanin or $\mathrm{GAL}_{2}$, or the addition of exogenous galanin or Gal2-11 modulate the survival of cultured hippocampal neurons under excitotoxic conditions where apoptotic cell death occurs $[35,36,46]$. More recently these studies have been 

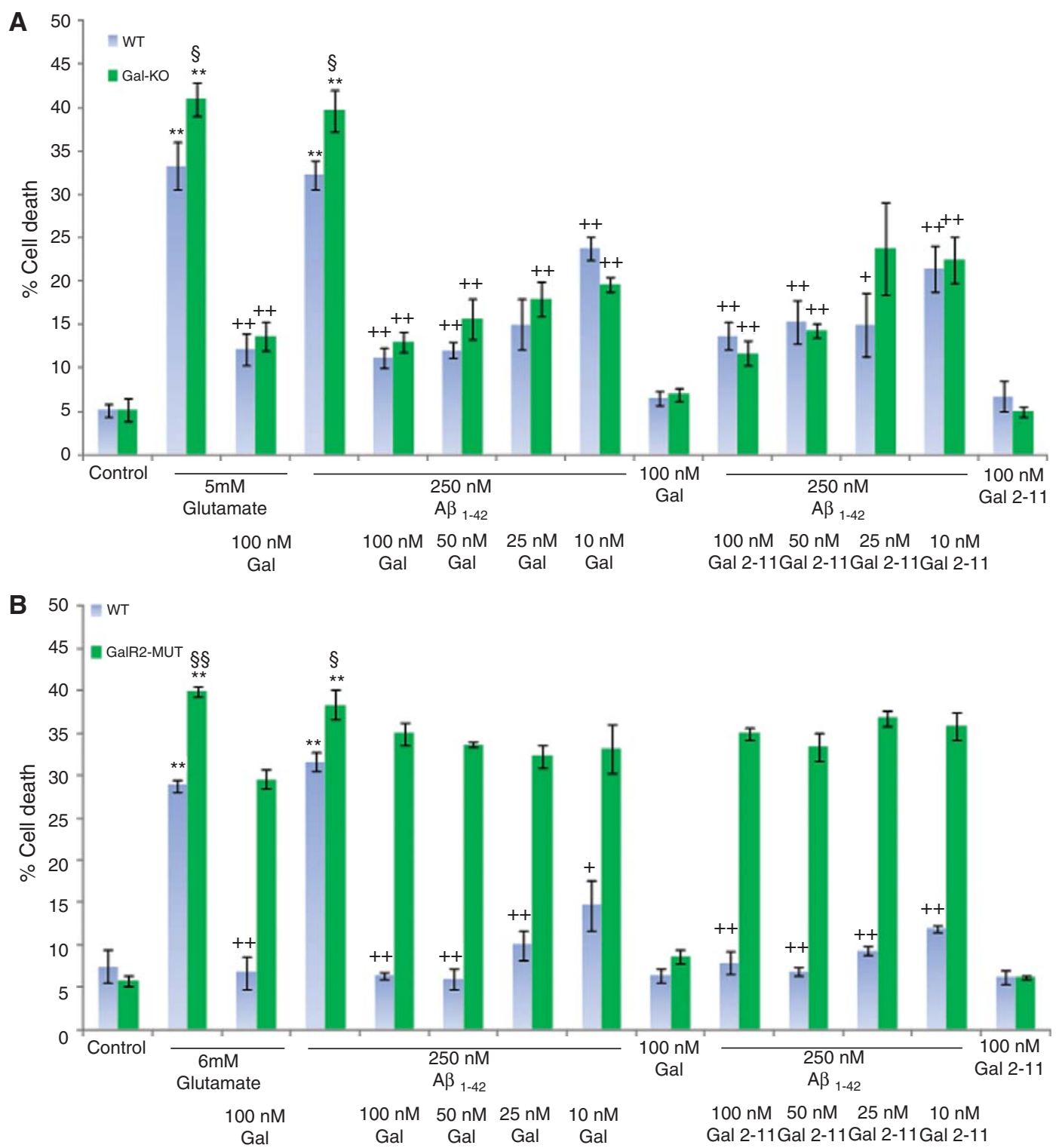

Fig. 1. Percentage cell death in (A) Gal-KO and (B) GAL2-MUT both compared to strain matched WT hippocampal cultures, treated with $250 \mathrm{nM}$ fA_1-42 in the presence of varying concentrations of galanin or Gal2-11. In both loss-of-function mutations there is a significant increase in fA_1-42 and glutamate-induced cell death compared to strain-matched WT cultures. Addition of galanin or Gal2-11 significantly rescues the deficits in the Gal-KO but not the GAL2-MUT cultures. ${ }^{* *} p<0.01$ treatment versus control. $\$ p<0.05$ Gal-KO or GAL2-MUT versus WT. $\S \S p<0.01$ GAL2-MUT versus WT. $+p<0.05$ treatment different to fA_1 $1-42$ or glutamate alone. $++p<0.01$ treatment different to fA_1-42 or glutamate alone.

extended to $A \beta$-induced neuronal apoptosis. Treatment of cultured human embryonic cortical neurons with galanin significantly inhibited $A \beta$-induced cell death [39]. Similarly, galanin and Gal2-11 both significantly reduced $A \beta$ toxicity in primary rat hippocampal [37] or cholinergic [38] neuronal cultures, and in cholinergic septal neuron 56 cells (a hybrid of mouse septal neurons and N18TG2 neuroblastoma cells) [40].
In the present study, we provide additional data demonstrating that exogenous galanin or Gal2-11 both provide significant neuroprotection against $A \beta$ or glutamate toxicity in three different WT strains, confirming the above data sets. Moreover, we have now extended these findings using a panel of previously characterized transgenic mice with loss-of-function mutations in galanin or $\mathrm{GAL}_{2}$ and over-expression 


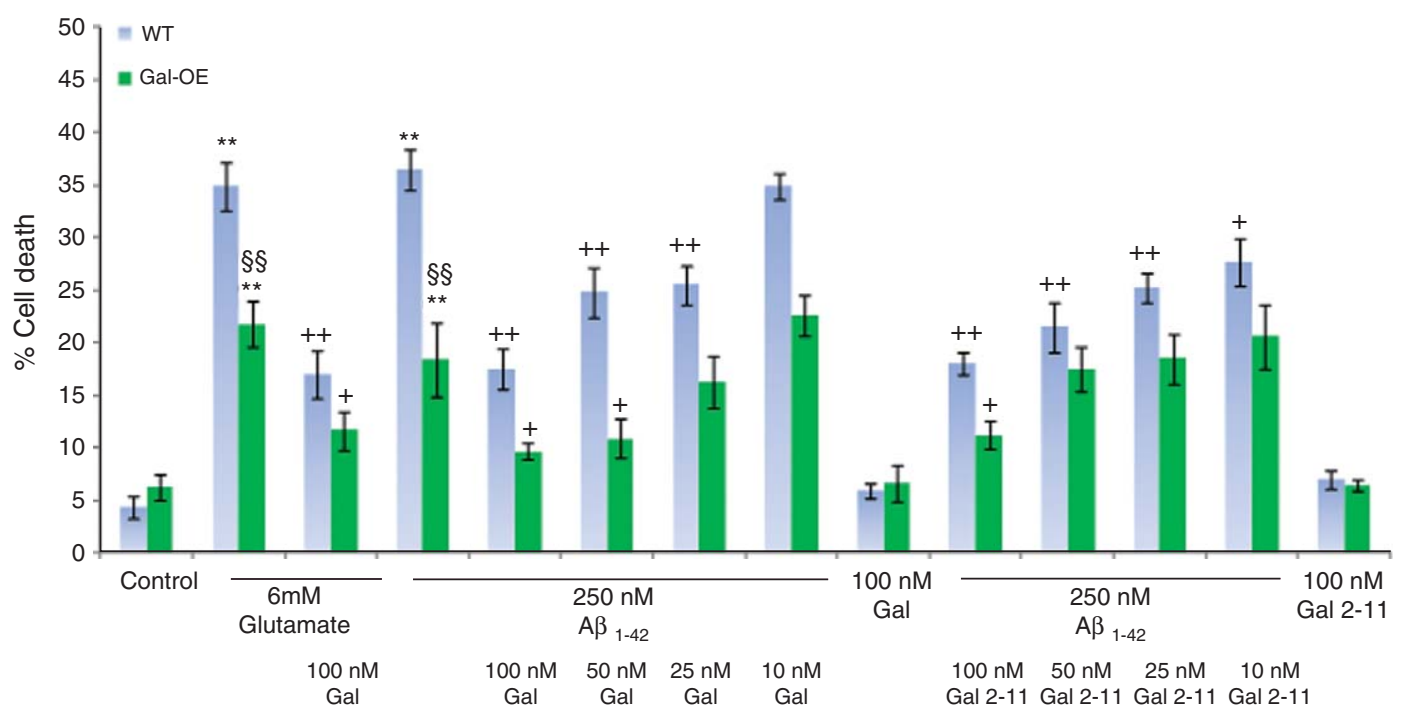

Fig. 2. Percentage cell death in Gal-OE and strain matched WT hippocampal cultures treated with $250 \mathrm{nM}$ fA_1-42 in the presence of varying concentrations of galanin or Gal2-11. In the Gal-OE mice there is a significant decrease in fA_1-42 and glutamate-induced cell death compared to strain-matched WT cultures. Addition of $100 \mathrm{nM}$ and $50 \mathrm{nM}$ galanin or $100 \mathrm{nM} \mathrm{Gal2}-11$ further and significantly rescues the cell death. ${ }^{* *} p<0.01$ treatment versus control. $\S \S p<0.01 \mathrm{Gal}-\mathrm{OE}$ versus WT. $+p<0.05$ treatment different to fA_1 -42 or glutamate alone. $++p<0.01$ treatment different to fA_1-42 or glutamate alone.

of galanin in the CNS using the previously described $20 \mathrm{~kb}$ galanin promoter region [35]. A $\beta$-induced cell death is significantly increased in Gal-KO and $\mathrm{GAL}_{2-}$ MUT mice and reduced in Gal-OE transgenic mice, each compared to strain-matched WT controls. Importantly, exogenous galanin or Gal2-11 fully rescue the deficits in the Gal-KO but have no effect in the $\mathrm{GAL}_{2}$ MUT mice lacking a functional $\mathrm{GAL}_{2}$. Since activation of $\mathrm{GAL}_{1}$ and $\mathrm{GAL}_{3}$ by galanin, and $\mathrm{GAL}_{3}$ by Gal211 had no protective effects in the $\mathrm{GAL}_{2}$-MUT mice, these findings add further weight to the hypothesis that the galanin over-expression seen in AD is a neuroprotective response, mediated by activation of $\mathrm{GAL}_{2}$. We are currently extending these in vitro findings into an in vivo model of $\mathrm{A} \beta$-induced neuronal dysfunction by crossing the Gal-OE mice to an A $\beta P P / P S 1$ expressing line and then studying whether the over-expression of galanin modulates the previously described cognitive deficits in that line.

The intracellular signaling pathways that mediate the neuroprotective effects of $\mathrm{GAL}_{2}$ activation have yet to be fully defined. GAL 2 couples to both $\mathrm{G}_{\mathrm{i} / \mathrm{o}}$ and inhibits adenylyl cyclase [47] and also signals via $\mathrm{G}_{\mathrm{q} / 11}$ to activate phospholipase $\mathrm{C}$ (PLC) and protein kinase C (PKC) [47, 48]. Our previous studies using cultured hippocampal or sensory neurons have shown that the addition of galanin rapidly and potently stimulates phosphorylation of the serine/threonine kinase Akt and extracellular signal-regulated kinases (ERK)
$[32,36]$. These findings are also consistent with previous publications that hippocampal protection after excitotoxic damage is dependent in part upon activation of ERK [49, 50] and/or Akt [51, 52]. Recent data demonstrates that the neuroprotective effects of galanin against $A \beta$-induced apoptosis, are mediated by: (a) reversal of the $A \beta$-induced reduction in pERK and pAkt [38], (b) down-regulation of Bax levels [37, 39], and (c) attenuation in the cleavage of caspase 3 [37, 38, 40].

Irrespective of which signaling pathways mediate the neuroprotective effects of $\mathrm{GAL}_{2}$ activation, our findings that the addition of exogenous galanin or Gal2-11 in Gal-OE mice further reduces apoptosis, is of considerable interest in the context of the raised levels of galanin reported in $\mathrm{AD}$ [41]. This result implies that $\mathrm{GAL}_{2}$-mediated neuroprotection is not yet at maximum in situations where endogenous galanin expression is raised. This further supports the premise that the development of drug-like $\mathrm{GAL}_{2}$ agonists or positive allosteric modulators (as recently described [53]) might reduce the progression of symptoms in patients with $\mathrm{AD}$.

\section{ACKNOWLEDGMENTS}

This work was supported by The Wellcome Trust and National Institute on Aging grant AG10668. 
Authors' disclosures available online (http://www.jalz.com/disclosures/view.php?id=784).

\section{REFERENCES}

[1] Haass C, Selkoe DJ (1993) Cellular processing of betaamyloid precursor protein and the genesis of amyloid beta-peptide. Cell 75, 1039-1042.

[2] Glenner GG, Wong CW (1984) Alzheimer's disease: initial report of the purification and characterization of a novel cerebrovascular amyloid protein. Biochem Biophys Res Commun 120, 885-890.

[3] Lombardo JA, Stern EA, McLellan ME, Kajdasz ST, Hickey GA, Bacskai BJ, Hyman BT (2003) Amyloid-beta antibody treatment leads to rapid normalization of plaque-induced neuritic alterations. $J$ Neurosci 23, 10879-10883.

[4] Selkoe DJ (1996) Amyloid beta-protein and the genetics of Alzheimer's disease. J Biol Chem 271, 18295-18298.

[5] Selkoe DJ (2002) Alzheimer's disease is a synaptic failure. Science 298, 789-791.

[6] Bierer LM, Haroutunian V, Gabriel S, Knott PJ, Carlin LS, Purohit DP, Perl DP, Schmeidler J, Kanof P, Davis KL (1995) Neurochemical correlates of dementia severity in Alzheimer's disease: relative importance of the cholinergic deficits. $\mathrm{J} \mathrm{Neu-}$ rochem $\mathbf{6 4}, 749-760$.

[7] Tatemoto K, Rokaeus A, Jornvall H, McDonald TJ, Mutt V (1983) Galanin - a novel biologically active peptide from porcine intestine. FEBS Lett 164, 124-128.

[8] Evans HF, Shine J (1991) Human galanin: molecular cloning reveals a unique structure. Endocrinology 129, 1682-1684.

[9] Chan-Palay V (1988) Galanin hyperinnervates surviving neurons of the human basal nucleus of Meynert in dementias of Alzheimer's and Parkinson's disease: a hypothesis for the role of galanin in accentuating cholinergic dysfunction in dementia. J Comp Neurol 273, 543-557.

[10] Mufson EJ, Cochran E, Benzing W, Kordower JH (1993) Galaninergic innervation of the cholinergic vertical limb of the diagonal band (Ch2) and bed nucleus of the stria terminalis in aging, Alzheimer's disease and Down's syndrome. Dementia 4, 237-250.

[11] Bowser R, Kordower JH, Mufson EJ (1997) A confocal microscopic analysis of galaninergic hyperinnervation of cholinergic basal forebrain neurons in Alzheimer's disease. Brain Pathol 72, 723-730.

[12] Chan-Palay V (1991) Alterations in the locus coeruleus in dementias of Alzheimer's and Parkinson's disease. Prog Brain Res 88, 625-630.

[13] Gabriel SM, Knott PJ, Haroutunian V (1995) Alterations in cerebral cortical galanin concentrations following neurotransmitter-specific subcortical lesions in the rat. $\mathrm{J} \mathrm{Neu}$ rosci 15, 5526-5534.

[14] Mufson EJ, Deecher DC, Basile M, Izenwasse S, Mash DC (2000) Galanin receptor plasticity within the nucleus basalis in early and late Alzheimer's disease: an in vitro autoradiographic analysis. Neuropharmacology 39, 1404-1412.

[15] Rodriguez-Puertas R, Nilsson S, Pascual J, Pazos A, Hokfelt T (1997) 125I-galanin binding sites in Alzheimer's disease: increases in hippocampal subfields and a decrease in the caudate nucleus. J Neurochem 68, 1106-1113.

[16] Perez S, Basile M, Mash DC, Mufson EJ (2002) Galanin receptor over-expression within the amygdala in early Alzheimer's disease: an in vitro autoradiographic analysis. J Chem Neuroanat 24, 109-116.
[17] McMillan PJ, Peskind E, Raskind MA, Leverenz JB (2004) Increased galanin receptor occupancy in Alzheimer's disease. Neurobiol Aging 25, 1309-1314.

[18] Mufson EJ, Counts SE, Perez SE, Binder L (2005) Galanin plasticity in the cholinergic basal forebrain in Alzheimer's disease and transgenic mice. Neuropeptides 39, 233-237.

[19] Diez M, Danner S, Frey P, Sommer B, Staufenbiel M, Wiederhold KH, Hokfelt T (2003) Neuropeptide alterations in the hippocampal formation and cortex of transgenic mice overexpressing beta-amyloid precursor protein (APP) with the Swedish double mutation (APP23). Neurobiol Dis 14, 579594.

[20] Wrenn CC, Crawley JN (2001) Pharmacological evidence supporting a role for galanin in cognition and affect. Prog Neuro-Psychoph 25, 283-299.

[21] Sundstrom E, Archer T, Melander T, Hokfelt T (1988) Galanin impairs acquisition but not retrieval of spatial memory in rats studied in the Morris swim maze. Neurosci Lett 88, 331-335.

[22] Schott PA, Hokfelt T, Ogren SO (2000) Galanin and spatial learning in the rat. Evidence for a differential role for galanin in subregions of the hippocampal formation. Neuropharm $\mathbf{3 9}$, 1386-1403.

[23] Ogren SO, Schott PA, Kehr J, Misane I, Razani H (1999) Galanin and learning. Brain Res 848, 174-182.

[24] Valkna A, Jureus A, Karelson E, Zilmer M, Bartfai T, Langel U (1995) Differential regulation of adenylate cyclase activity in rat ventral and dorsal hippocampus by rat galanin. Neurosci Lett 187, 75-78.

[25] Steiner RA, Hohmann JG, Holmes A, Wrenn CC, Cadd G, Jureus A, Clifton DK, Luo M, Gutshall M, Ma SY, Mufson EJ, Crawley JN (2001) Galanin transgenic mice display cognitive and neurochemical deficits characteristic of Alzheimer's disease. Proc Natl Acad Sci U S A 98, 41844189.

[26] Kuteeva E, Hokfelt T, Ove OS (2005) Behavioural characterisation of transgenic mice overexpressing galanin under the PDGF-B promoter. Neuropeptides 39, 297-302.

[27] Holmes FE, Bacon A, Pope RJ, Vanderplank PA, Kerr NC, Sukumaran M, Pachnis V, Wynick D (2003) Transgenic overexpression of galanin in the dorsal root ganglia modulates pain-related behavior. Proc Natl Acad Sci U S A 100, 61806185.

[28] Wynick D, Small CJ, Bacon A, Holmes FE, Norman M, Ormandy CJ, Kilic E, Kerr NCH, Ghatei M, Talamantes F, Bloom SR, Pachnis V (1998) Galanin regulates prolactin release and lactotroph proliferation. Proc Natl Acad Sci U S A 95, 12671-12676.

[29] Holmes FE, Mahoney S, King VR, Bacon A, Kerr NCH, Pachnis V, Curtis R, Priestley JV, Wynick D (2000) Targeted disruption of the galanin gene reduces the number of sensory neurons and their regenerative capacity. Proc Natl Acad Sci U S A 97, 11563-11568.

[30] O’Meara G, Coumis U, Ma SY, Kehr J, Mahoney S, Bacon A, Allen SJ, Holmes F, Kahl U, Wang FH, Kearns IR, Ove-Ogren S, Dawbarn D, Mufson EJ, Davies C, Dawson G, Wynick D (2000) Galanin regulates the postnatal survival of a subset of basal forebrain cholinergic neurons. Proc Natl Acad Sci U S A 97, 11569-11574.

[31] Mahoney SA, Hosking R, Farrant S, Holmes FE, Jacoby AS, Shine J, Iismaa TP, Scott MK, Schmidt R, Wynick D (2003) The second galanin receptor GalR2 plays a key role in neurite outgrowth from adult sensory neurons. J Neurosci $\mathbf{2 3}$, 416421.

[32] Hobson SA, Holmes FE, Kerr NCH, Pope RJ, Wynick D (2006) Mice deficient for galanin receptor 2 have decreased 
neurite outgrowth from adult sensory neurons and impaired pain-like behaviour. J Neurochem 99, 1000-1010.

[33] Liu HX, Brumovsky P, Schmidt R, Brown W, Payza K, Hodzic L, Pou C, Godbout C, Hokfelt T (2001) Receptor subtypespecific pronociceptive and analgesic actions of galanin in the spinal cord: selective actions via GalR1 and GalR2 receptors. Proc Natl Acad Sci U S A 98, 9960-9964.

[34] Lu X, Lundstrom L, Bartfai T (2005) Galanin (2-11) binds to GalR3 in transfected cell lines: limitations for pharmacological definition of receptor subtypes. Neuropeptides $\mathbf{3 9}$, $165-167$.

[35] Elliott-Hunt CR, Marsh B, Bacon A, Pope R, Vanderplank P, Wynick D (2004) Galanin acts as a neuroprotective factor to the hippocampus. Proc Natl Acad Sci U S A 101, 5105-5110.

[36] Elliott-Hunt CR, Pope RJ, Vanderplank P, Wynick D (2007) Activation of the galanin receptor 2 (GalR2) protects the hippocampus from neuronal damage. JNeurochem 100, 780-789.

[37] Cheng Y, Yu LC (2010) Galanin protects amyloid-betainduced neurotoxicity on primary cultured hippocampal neurons of rats. J Alzheimers Dis 20, 1143-1157.

[38] Ding X, MacTavish D, Kar S, Jhamandas JH (2006) Galanin attenuates beta-amyloid (Abeta) toxicity in rat cholinergic basal forebrain neurons. Neurobiol Dis 21, 413-420.

[39] Cui J, Chen Q, Yue X, Jiang X, Gao GF, Yu LC, Zhang Y (2010) Galanin protects against intracellular amyloid toxicity in human primary neurons. J Alzheimers Dis 19, 529-544.

[40] Pirondi S, Giuliani A, Del VG, Giardino L, Hokfelt T, Calza L (2010) The galanin receptor $2 / 3$ agonist Gal2-11 protects the SN56 cells against beta-amyloid 25-35 toxicity. $J$ Neurosci Res 88, 1064-1073.

[41] Counts SE, He B, Che S, Ginsberg SD, Mufson EJ (2009) Galanin fiber hyperinnervation preserves neuroprotective gene expression in cholinergic basal forebrain neurons in Alzheimer's disease. J Alzheimers Dis 18, 885-896.

[42] Bacon A, Holmes FE, Small CJ, Ghatei M, Mahoney S, Bloom SR, Wynick D (2002) Transgenic over-expression of galanin in injured primary sensory neurons. Neuroreport 13, 21292132 .

[43] Zambrowicz BP, Abuin A, Ramirez-Solis R, Richter LJ, Piggott J, BeltrandelRio H, Buxton EC, Edwards J, Finch RA, Friddle CJ, Gupta A, Hansen G, Hu Y, Huang W, Jaing C, Key BW Jr, Kipp P, Kohlhauff B, Ma ZQ, Markesich D, Payne R, Potter DG, Qian N, Shaw J, Schrick J, Shi ZZ, Sparks MJ, Van SI, Vogel P, Walke W, Xu N, Zhu Q, Person C, Sands AT
(2003) Wnk1 kinase deficiency lowers blood pressure in mice: a gene-trap screen to identify potential targets for therapeutic intervention. Proc Natl Acad Sci U S A 100, 14109-14114.

[44] Armstrong SP, Caunt CJ, Finch AR, Mcardle CA (2011) Using automated imaging to interrogate gonadotrophinreleasing hormone receptor trafficking and function. Mol Cell Endocrinol 331, 194-204.

[45] Caunt CJ, Armstrong SP, Mcardle CA (2010) Using high-content microscopy to study gonadotrophin-releasing hormone regulation of ERK. Methods Mol Biol 661, 507-524.

[46] Pirondi S, Fernandez M, Schmidt R, Hokfelt T, Giardino L, Calza L (2005) The galanin-R2 agonist AR-M1896 reduces glutamate toxicity in primary neural hippocampal cells. $J$ Neurochem 95, 821-833.

[47] Wang S, Hashemi T, Fried S, Clemmons AL, Hawes BE (1998) Differential intracellular signaling of the GalR1 and GalR2 galanin receptor subtypes. Biochemistry (Mosc) 37, 6711-6717.

[48] Wittau N, Grosse R, Kalkbrenner F, Gohla A, Schultz G, Gudermann T (2000) The galanin receptor type 2 initiates multiple signaling pathways in small cell lung cancer cells by coupling to $\mathrm{G}(\mathrm{q}), \mathrm{G}(\mathrm{i})$ and $\mathrm{G}(12)$ proteins. Oncogene 19, 4199-4209.

[49] Maher P (2001) How protein kinase C activation protects nerve cells from oxidative stress-induced cell death. $\mathrm{J} \mathrm{Neu}$ rosci 21, 2929-2938.

[50] Ozawa H, Shioda S, Dohi K, Matsumoto H, Mizushima H, Zhou CJ, Funahashi H, Nakai Y, Nakajo S, Matsumoto K (1999) Delayed neuronal cell death in the rat hippocampus is mediated by the mitogen-activated protein kinase signal transduction pathway. Neurosci Lett 262, 57-60.

[51] Culmsee C, Gerling N, Lehmann M, Nikolova-Karakashian M, Prehn JH, Mattson MP, Krieglstein J (2002) Nerve growth factor survival signaling in cultured hippocampal neurons is mediated through TrkA and requires the common neurotrophin receptor P75. Neuroscience 115, 1089-1108.

[52] Gary DS, Milhavet O, Camandola S, Mattson MP (2003) Essential role for integrin linked kinase in Akt-mediated integrin survival signaling in hippocampal neurons. J Neurochem 84, 878-890.

[53] Lu X, Roberts E, Xia F, Sanchez-Alavez M, Liu T, Baldwin R, Wu S, Chang J, Wasterlain CG, Bartfai T (2010) GalR2positive allosteric modulator exhibits anticonvulsant effects in animal models. Proc Natl Acad Sci U S A 107, 15229-15234. 